\title{
Poverty and poor education are key determinants of high household food insecurity among populations adjoining forest concessions in the Congo Basin
}

Pauline Donn ${ }^{1,4,7}$, Judith Laure Ngondi ${ }^{4,7^{*}}$, Julius Chupezi Tieguhong ${ }^{1,7}$, Donald Midoko Iponga ${ }^{5}$, Obadia Tchingsabe ${ }^{3,7}$, Robert Fungo ${ }^{6}$, Mathurin Tchatat $^{3}$ and Jean Marie Kahindo ${ }^{2}$

\begin{abstract}
Background: The trees and non-timber forest products (NTFPs) of the Congo Basin play a key role in alleviating food insecurity among millions of people around the world. Although many studies have been conducted both nationally and regionally on issues of food insecurity in the Congo Basin, little is known on the effects of timber exploitation on household food insecurity statues of forest dependent communities in this region. This study focused on the determination of the principal indicators of household food security status of populations living around six selected forest concessions in the Congo Basin.
\end{abstract}

Method: We randomly surveyed 724 households in thirty-four communities living in six popular forest concessions around the Congo Basin. Food consumption pattern data was collected using a validated food-frequency questionnaire in 2012. Household Food Insecurity Access Prevalence (HFIAP) was assessed using the HFIAP indicator and households were categorized into four levels of household food insecurity status as follows: Food secure (HFIAS =0); mildly food insecure (HFIAS 1-8); moderately food insecure (HFIAS 9-13); and severely food insecure (HFIAS 14-27).

Results: The majority of the households interviewed were headed by women $(73.1 \%, 76.6 \%$, and $58.6 \%$ for Cameroon, DRC and Gabon respectively), most of them married (84.6\%, $100 \%, 57.6 \%$ for Cameroon, DRC and Gabon respectively) with an average age range of 30-49 years. Most of the household members were engaged in farming and/or illegal logging as the main revenue generating activities. Results of global household food insecurity categorized $63.8 \%$ of households in Cameroon as fully food secure and $36 \%$ as food insecure. In the DRC (92.9\%) and Gabon (92.7\%), almost all the survey households were categorized as either moderately or severely food insecure; clearly elucidating the existence of severe insufficiency in the quantity and quality of food meant for human nutrition in these areas. The means of household food insecurity scores for the DRC (17.40 \pm 4.15$)$ and Gabon (14.9 \pm 5.87$)$ were significantly higher when compared to the average score for Cameroon ((7.55 \pm 6.62$)$ at $p<0.0001$. This literally means that many of the households especially in DRC and Gabon face enormous difficulties in obtaining an adequate dietary energy supply. Gender (female), educational level (illiterate), and age (young) were positively correlated to food insecurity levels.

(Continued on next page)

\footnotetext{
* Correspondence: ngondijudithl@hotmail.com

${ }^{4}$ Department of Biochemistry, University of Yaounde 1, Yaounde, Cameroon

${ }^{7}$ The Regional Research Center for Sustainable Development,

RReCSuD-Cameroon, Yaounde, P.O. Box 33297, Cameroon

Full list of author information is available at the end of the article
} 


\begin{abstract}
(Continued from previous page)
Conclusion: Our results revealed that, despite the potential contribution of the Congo Basin forests, through enhancing access to different forms of quality foods such as bush meat, wild foods, and medicine, not forgetting the provision of agricultural land, local construction material, and income generation resources, the prevalence of food insecurity among the population adjoining forest concessions in the region is severe. This prevalence is alarming around forest concessions of the DRC and Gabon and in one concession of Cameroon. Given that poverty and poor education were positively correlated to household food insecurity, they were considered the paramount determinants of household food insecurity in this region.
\end{abstract}

Keywords: Household, Food insecurity, Forest-dwellers, Forest concessions, Congo Basin

\section{Background}

The Congo Basin forest is the largest contiguous moist tropical forest in the world surpassed only by the Amazon Basin forest. It belongs to the six central African countries: Cameroon, Central African Republic, Republic of Congo, Gabon, Equatorial Guinea and the Democratic Republic of Congo (DRC) and is managed in collaboration with intergovernmental, Nongovernmental and private sector organizations. The Congo basin forest plays a central role in securing the livelihood of millions of people around the world through the provision of construction materials, shelter, food, energy and medicine and equally offers global ecological services [1]. The Congo Basin forest equally attracts numerous conservationists, tourists and biodiversity scientist all over the globe thanks to its huge and unique biodiversity potential which exceeds ten thousand plant species, a thousand species of birds and four hundred species of mammals. The largest share of this basin belongs to Cameroon, DRC and Gabon with its highest proportion of forest coverage allocated to Cameroon and the DRC [2]. The Congo Basin forest is increasing under concession to logging and mining companies with the logging sector witnessing a dualistic configuration. It boasts a highly visible formal sector that is export oriented and dominated by large industrial groups with foreign capital and an informal sector that has long been underestimated and undervalued [2]. Industrial logging has become the most extensive use of land in Central Africa, with almost $450,000 \mathrm{~km}^{2}$ of forest currently under concession. Concessions were implemented as a means to control a rampaging timber industry while providing a source of accessible timber for sustainable harvest [2]. A forest concession is defined as a natural forested land with a maximum surface area of 200000 ha that is attributed by the state to a logging company for exploitation. Certified forest concessions by a third party organization have clear and verifiable social, economic and environmental safeguards and norms to respect during logging operations while the uncertified concessions are not and may not benefit from market premiums associated with certified forest products. The informal timber sector which is logging carried out by small-scale operators, who mainly operate illegally has long been overlooked by the national entities as well as the international community which over the past decades, is usually associated with forest degradation rather than deforestation [2].

Although sustainable forest management (SFM) in logging concessions has progressed over its ten years of implementation in Central Africa [3], the communities of the Congo Basin countries living around forest concessions are still highly underdeveloped, dwelling in abject poverty and highly discriminated, with over half of the population permanently living in rural areas. Studies have shown that logging severely depletes food and other important resources which form the basis of the livelihoods of many forest-dependent peoples. The logging industries open up forest zones; bringing in large groups of people to the forest who would need energy in all its forms. In addition to logging activities, infrastructural projects such as road and dam construction also uncover the forests and increase accessibility to hunters. A consequence of the effect of logging and opening up of forest zones is a reduction in food resources especially meat, fish, wild fruits and vegetables which are the central protein sources of forest depended populations [4]. In Central Africa, logging roads have rendered the forests highly accessible to poachers, some of whom are logging company employees, who publicly transport bush meat in logging trucks (http://www.worldwildlife.org/ places/congo-basin). Logging activities in the forest have exposed elephants and great apes into roaming in this region, leading to crop raiding [5] and food shortages in addition to the destruction of fruits and vegetable gardens, wild fruit trees and edible forest plants located on the edge of the forests. This loss in food certainly results to shortages and probably undernourishment in forest-dependent communities, putting children and women at the highest risk. In the Brazilian Amazon for example, a 1994 survey of hunger amongst indigenous peoples recorded high levels of malnutrition amongst Indians whose land was invaded by loggers leading to food insecurity $[6,7]$. Food insecurity can be defined as limited or uncertain availability 
of nutritionally adequate and safe food or better still as limited or uncertain ability to acquire acceptable food in socially acceptable ways $[8,9]$. In 1996, the World Food Summit $[10,11]$ explained that food insecurity exists when people lack secure access to sufficient amounts of safe and nutritious food for normal growth \& development, and an active \& healthy life.

Factors affecting household food security across developing countries, especially in Africa have been reported [12], with household size, educational level, gender, per capita aggregate production and cattle ownership being the predominant determinants at individual household and community levels. These reports further explain that an increase in family size tends to lay more burden on consumption than does labor on production and this is because food demand is a function of household size [13]. Education is an additional factor which is thought to influence the food security status of households [14] even though its relationship to food security status of a household has not been clearly established. It is known that wealth status, often translated into per capita aggregate production affects the food security of households through price effects, as a drop for instance in food prices in local markets will likely negatively influence households whose income is dependent on the sale of food crops [15]. Livestock contribute to household livelihood in many ways, including: source of pulling power (reserved to cattle) [16], source of cash income, source of supplementary food like milk and meat, and as a means of transport (cattle, donkeys, horses, etc.).

Although the countries in the Congo Basin have collectively made progress towards achieving the Millennium Development Goal of reducing hunger by half in 2015, research results show that some communities in these countries live in a vicious cycle of food insecurity and malnutrition [17]. In particular, the DRC and Central African Republic still harbor about $70 \%$ of people lacking access to adequate food [18]. The MICS survey [19] identified an average of $33 \%$ of food insecure households in the DRC, grouping the country into four provinces as a function of food insecurity levels. The World Food Program (WFP) considers Cameroon as a food insecure country, and has further demonstrated that food intake in households is currently lower than was in the early 1980s [17]. Several research papers highlight the importance of ecosystems such as forests in food security [ 1 and other references therein]. Forests positively contribute to household food security in many communities Worldwide through the provision of both staple and supplemental foods in addition to commercial forest products that directly generate income [19]. For the majority of rural people, forest food adds variety to diets, improves palatability, and provides essential vitamins, minerals, protein and calories [20]. Although many studies have been conducted on issues related to food insecurity at national and regional levels in the Congo Basin, little has been done to understand food security problems at the household level in specific locations, particularly for people living adjacent to forest concessions. Considering the fact that timber exploitation is putting increasing pressure on local biodiversity with potential negative repercussions on food security and livelihoods [21], and the need to understand food insecurity causes at household level, this study is aimed at investigating the food security status of households around forest concessions and at examining the principal determinants of household food insecurity in the Congo Basin.

\section{Methods}

\section{Study Population and Settings}

The study was carried out under the framework of the "Beyond Timber project" to respond to the urgent needs of suitable forest management approaches that can reconcile the interests of the growing logging industry in the Congo Basin with those of forest dependent people. This study was carried out in 34 communities of 6 forest concessions adjoining the Congo Basin. These concessions fall within 3 countries (Cameroon, Gabon and DRC) holding more than $80 \%$ of the Congo Basin forest. The criteria used for the selection of the study sites were based on: type of concession (certified or non-certified, local or international), existence of trees of multiple use (timber/ food value), the existence of a management plan, easy access to site for the research team, the willingness of the forest concessionaires and the local community to participate (including a long-term follow-up) in the study, existence of baseline information, and the presence of a high population density and a great variability of ethnic groups. The six concessions selected were: SCTB: Société Camerounaise de Transformation du Bois; FIPCAM: Fabrique Camerounaise de Parquet; BAYONNE: SUN HARVEST Bayonne; CEB: Compagnie Equatoriale des Bois; COTREFOR: Compagnie de Transport et d'Exploitation Forestière; CFT: Compagnie Forestière de Transformation.

\section{Selection of villages and households}

A three-stage cluster sampling technique involving one stage of purposeful selection and two stages of randomization were used in the selection of the study villages and households. Firstly, districts within each site were purposefully selected on the basis of their accessibility, ethnicity, and willingness of the community to participate in the study and existence of the logging activities in the surrounding forests. Secondly, villages were randomly selected within the chosen two districts and thirdly, households were randomly selected. The 
survey was simultaneously conducted in all the six concessions during the 2012 year. The structure of the questionnaire was presented to household heads following their willingness to participate in the study while supervision or follow-up was assured by technicians or local partners.

\section{Evaluation of food security}

The food security assessment methodology developed by the Food and Nutrition Technical Assistance (FANTA) project was used to assess whether or not households had experienced problems regarding access to food during the last 30 days [22]. The Fanta Project methodology is adapted to explore and test alternative measures of household food insecurity throughout the world in a variety of cultural contexts. Various indicators and scales to measure aspects of food insecurity have been developed and designed to measure food access and have been successfully used in many African countries [23]. The Household Food Insecurity Access Scale (HFIAS) questionnaire of the FANTA methodology is composed of 9 questions related to the modifications that households can make to their diet or their model of food consumption due to lack of resources to obtain food. Three indicators derived from these questions were used to understand the characteristics and changes in household food insecurity (access) in the study population:

\section{Household Food Insecurity Access-related Domains (Household Food Insecurity Access Scale Score and Household Food Insecurity Access Prevalence):}

The first indicator is based on occurrence questions related to three different domains of food insecurity (access): Anxiety and uncertainty about the household food supply; insufficient quality (includes variety), food type preference and insufficient food intake and its physical consequences.

\section{Household Food Insecurity Access Scale (HFIAS)}

The HFIAS score is a continuous measure of the degree of food insecurity (access) in a household during the previous month. An HFIAS score is calculated for each household based on answers to the nine 'frequency-ofoccurrence' questions. The minimum score is 0 and the maximum is 27; "the higher the score, the more food insecure a household is" and vice versa.

\section{Household Food Insecurity Access Prevalence (HFIAP)}

The HFIAP indicator categorizes households into four levels of household food insecurity (access): Households were divided into four Categories of food insecurity as follows: Food secure (HFIAS $=0$ ); mildly food insecure (HFIAS 1-8); moderately food insecure (HFIAS 9-13); and severely food insecure (HFIAS 14-27). Households categorized as increasingly food insecure respond affirmatively to more severe conditions and/or experience those conditions more frequently.

\section{Determination of Socioeconomic status (SES)}

The socioeconomic status of the households was determined using the household wealth index described by Garenne and Hohmann [24]. Wealth index assess the number of modern goods owned by individual households such as bicycle, television, radio, motorcycle, telephone, cars, refrigerator as well as housing quality (floor, walls, and roof material). Poverty was estimated using the proportion of households possessing less than three modern goods.

\section{Data analysis methodology}

Households in communities around the two selected forest concessions of each country were used for comparative purposes. For variables expressed as percentages or proportions, chi-square test was used to assess differences between food security classifications. Differences between means or proportions were considered statistically significant if $\mathrm{p}<0.05$. Logistic regression models were used to quantify the association between household food security and socioeconomic/ demographic variables.

\section{Results}

Socioeconomic and demographic characteristics

As shown in Table 1, the majority of household heads interviewed were females; about $73.1 \%$ in Cameroon, $76.7 \%$ in DRC and $58.6 \%$ in Gabon. In Cameroon and DRC, most of them aged between 30-49 years while in Gabon 39.9 \% were above 50 years. In terms of marital status, most of them were married and the highest percentage was noticed in DRC (100 \%), followed by Cameroon (84.6\%) and $57.6 \%$ in Gabon. Results revealed a low level of household heads with no formal education in DRC (22.4\%) and Gabon (30 \%) while the remaining were averagely literate ranging from primary to secondary school level.

\section{Household Food Insecurity Access-related Domains}

This indicator is based on occurrence questions related to three different domains of food insecurity (access): anxiety, uncertainty about the household food supply and insufficient quality (including variety). The results in Table 2 show that the proportion of household heads who responded affirmatively to food security occurrence questions was low in Cameroon and this was more evident around FIPCAM compare to the SCTB concession. In the DRC and Gabon, more than $90 \%$ of household heads responded affirmatively to the nine questions. 
Table 1 Socioeconomic/demographic characteristics

\begin{tabular}{|c|c|c|c|c|}
\hline Variables & & Cameroon & DRC & Gabon \\
\hline \multirow[t]{2}{*}{ Sex of family head } & Female & 73.1 & 76.7 & 55.5 \\
\hline & Male & 26.9 & 23.3 & 44.5 \\
\hline \multirow[t]{3}{*}{ Marital status } & Single & 9.3 & & 25.2 \\
\hline & Married & 84.6 & 100 & 57.6 \\
\hline & Widow/Divorce & 6,1 & & 17.2 \\
\hline \multirow[t]{4}{*}{ Primary occupation } & Farming /illegal logging & 96.1 & 100 & 73.9 \\
\hline & Worker & 2,4 & & 6.3 \\
\hline & Trader & 1.1 & & 2.7 \\
\hline & Retired & 0.4 & & 17.1 \\
\hline \multirow[t]{5}{*}{ Age of the family head(Years) } & $\leq 30$ & 17.7 & 29.6 & 3.9 \\
\hline & $31-39$ & 21.3 & 14.8 & 12.4 \\
\hline & $40-49$ & 23.1 & 18.5 & 21.9 \\
\hline & $50-59$ & 22.7 & 13 & 22.5 \\
\hline & 60 and above & 15.2 & 24.1 & 39.3 \\
\hline \multirow[t]{4}{*}{ Level of education } & No formal education & 4.7 & 22.4 & 30.7 \\
\hline & Primary education & 63.6 & 56.9 & 39.1 \\
\hline & Secondary education & 31 & 20.7 & 28.6 \\
\hline & University & 0.7 & & 1.6 \\
\hline \multirow[t]{2}{*}{ Source of potable water } & Unprotected & 79,7 & 100 & 71,3 \\
\hline & Protected & 20,3 & & 28,7 \\
\hline \multicolumn{5}{|l|}{ Quality of roof material } \\
\hline & Roofingtile & 2.5 & & 7.8 \\
\hline & Metal roof & 62.5 & & 92.2 \\
\hline & thatch & 2.9 & 30 & \\
\hline & Marantaceae /other leaves & 32.1 & 70 & \\
\hline Ownership of household durable goods & $\begin{array}{l}\text { Motorcycle } \\
\text { Bicycle } \\
\text { Car } \\
\text { Refrigerator } \\
\text { Television } \\
\text { Radio } \\
\text { Electricity }\end{array}$ & $\begin{array}{l}27.4 \\
3.6 \\
3.2 \\
2.2 \\
36.8 \\
56.3 \\
44.8\end{array}$ & $\begin{array}{l}8.3 \\
88.4 \\
0 \\
0 \\
0 \\
100\end{array}$ & $\begin{array}{l}4.3 \\
0.9 \\
1.7 \\
1.7 \\
15.7 \\
14.3 \\
6,1\end{array}$ \\
\hline \multirow[t]{5}{*}{ Length of stay in the area } & $<1$ year & 3.5 & & 10,3 \\
\hline & $1-2$ years & 3.6 & & 1.1 \\
\hline & $>2<5$ years & 7.2 & & 5.9 \\
\hline & $4>5 \leq 10$ years & 6.1 & & 9.2 \\
\hline & $>10$ years & 79.6 & 100 & 73.5 \\
\hline \multirow[t]{4}{*}{ Place of residence before the study } & In another part of the forest & 9.3 & & 22.9 \\
\hline & In another forest & 12.9 & 1.6 & \\
\hline & Inside the forest & 3.2 & 90.9 & 3.1 \\
\hline & In the same part of the forest & 74.6 & 7.5 & 74 \\
\hline \multirow[t]{5}{*}{ Main source of income } & Salary & 3.6 & & 2.7 \\
\hline & Occasional odd jobs & 3 & & 0.9 \\
\hline & Agriculture & 43.4 & 100 & 94.6 \\
\hline & Illegal logging & 1.4 & & 1.8 \\
\hline & Agriculture\&trading & 14.1 & & \\
\hline
\end{tabular}


Table 1 Socioeconomic/demographic characteristics (Continued)

\begin{tabular}{llll}
\hline & Agriculture \& illegal logging & 34.5 & \\
Household wealth index scores & $0-1$ & 15.2 & 100 \\
& $2-4$ & 53.5 & 54.4 \\
& $5-7$ & 31.5 & 45.6 \\
\hline
\end{tabular}

\section{Household Food Insecurity Access Scale (HFIAS)}

Variations in the household food insecurity access scale on the 0-27 HFIAS between the three countries are presented in Table 3. The average household food insecurity score in Cameroon $(7.5 \pm 6.6)$ was significantly lower when compare to Gabon $(14.9 \pm 5.9)$ and the DRC $(17.4 \pm 4.2)$. This means that in comparison to households in communities adjoining the forest concessions of Cameroon, a greater percentage of households around the DRC and Gabon forest concessions lack both access to quantity and quality food to meet their nutritional needs and also lack food preferences for maintaining a healthy living. The average score was also significantly different within forest concessions in each country. In Cameroon, the average household food insecurity score around SCTB concession was significantly higher compare to FIPCAM (11.1 vs. 3.3) at $\mathrm{p}<0.0001$, while in Gabon the average score was significantly higher around CEB compare to Bayonne (15.5 vs. 13.3) at $\mathrm{P}<0.03$. The same pattern was noticed in the DRC with the average score higher around CFT concession than in the COTREFOR (15.8 vs. 19.0) at $\mathrm{P}<0.0001$. The mean of average food insecurity was significantly different $(\mathrm{p}<0.0001)$ among the three countries.

\section{Household Food Insecurity access prevalence (HFIAP) around the six forest concessions}

The classification of households into the four HFIAP food security categories for each of the six forest concessions is presented in Fig. 1. In Cameroon, the highest prevalence of food insecurity was noticed around the SCTB concession of the east region where approximately $13.6 \%$ of households were classified as mildly food insecure and $50.7 \%$ as severely food insecure with only $1.6 \%$ severely food insecure around the FIPCAM (South region) concession. The prevalence of food security between the two concessions was highly significant $\left(\left(X^{2}=116.97 ; p<0.0001\right)\right.$. In the DRC, although most of the studied households were food insecure, more severely food insecure households were noticed around CFT concession (100 \%) with significant differences when compared to COTREFOR concession (66.6\%; $\left.\mathrm{X}^{2}=18.22 ; \mathrm{p}<0.001\right)$. Similar patterns were found in Gabon where the percentage of households that experienced mild to severe food insecurity was significantly higher $\left(X^{2}=5.36 ; \quad \mathrm{p}<0.02\right)$ around $C E B$ concession $(28.5 \%$ \& $64.3 \%)$ compared to Bayonne $(19.2 \%$ \& $66.6 \%)$

It was noticed that households classified as mildly food insecure rarely experienced food deprivation; we then considered this category as food secure. Similarly, those classified as both moderately and severely food insecure were jointly considered as food insecure. Using this new classification, the distribution of households between the two categories of food security status (secure/insecure) showed that food insecurity was high around CFT (100 \%), CEB (95 \%); COTREFOR (85 \%), Bayonne (86\%), and SCTB (64\%). Almost all households (98\%) around FIPCAM concession in Cameroon were food secured (Fig. 2). Summarizing this classification at country

Table 2 Proportion of household heads responding affirmatively to food security constructs

\begin{tabular}{|c|c|c|c|c|c|c|}
\hline Countries & Cameroon & & DRC & & Gabon & \\
\hline Occurrence question around concessions & SCTB n(\%) & FIPCAM n(\%) & COTREFOR n(\%) & CFT n(\%) & BAYONNE n(\%) & CEB $\mathrm{n}(\%)$ \\
\hline Worry that your household would not have enough & $82(53.2)$ & $39(31.2)$ & $120(100)$ & $120(100)$ & $45(95.7)$ & $136(93.2)$ \\
\hline $\begin{array}{l}\text { Not able to eat the kind of food you preferred due to lack } \\
\text { of resources }\end{array}$ & $70(45.5)$ & $19(15,2)$ & $118(98.3)$ & $118(98.3)$ & 46(97.9) & $138(94.5)$ \\
\hline Eat limited variety of food because of lack of resources & $93(60.4)$ & $54(43.2)$ & $120(100)$ & $120(100)$ & 39(83) & $138(94.5)$ \\
\hline Eat food you really not want to eat because of lack of resources & $58(37.7)$ & $17(13.6)$ & $115(95.8)$ & $115(95.8)$ & $42(89.4)$ & $139(95.2)$ \\
\hline Eat a smaller meal than you felt to eat due to lack of resources & $49(31.8)$ & 19 (15.2) & $120(100)$ & 120(100) & $11(19.1)$ & $139(95.2)$ \\
\hline Eat fewer meal in a day due to there is no enough food & $58(37.7)$ & $22(17.6)$ & $120(100)$ & $120(100)$ & $11(23.4)$ & $138(94.5)$ \\
\hline No food to eat of any kind due to lack of resources & $59(38.3)$ & $31(24.8)$ & $120(100)$ & $120(100)$ & $9(13.1)$ & $139(95.2)$ \\
\hline $\begin{array}{l}\text { Member go to sleep at night hungry due to lack of } \\
\text { enough food }\end{array}$ & $99(64.3)$ & $51(40.8)$ & $120(100)$ & $120(100)$ & $43(91.5)$ & $140(95 ., 9)$ \\
\hline $\begin{array}{l}\text { Spent a whole day and night without eating because there } \\
\text { is no enough food }\end{array}$ & $106(68.8)$ & $68(54.4)$ & $120(100)$ & $120(100)$ & $46(97.9)$ & $139(95.2)$ \\
\hline
\end{tabular}


Table 3 Average household food insecurity scale around forest concessions of the Congo Basin

\begin{tabular}{|c|c|c|c|c|c|c|}
\hline Countries & Cameroon & & DRC & & Gabon & \\
\hline Forest Concession & FIPCAM & SCTB & COTREFOR & CFT & BAYONNE & CEB \\
\hline Average household food insecurity scale & $3.29 \pm 0.24^{*}$ & $11.01 \pm 0.55$ & $15.79 \pm 0.50$ & $19.00 \pm 00^{*}$ & $13.30 \pm 0.68$ & $15.49 \pm 0.50^{* *}$ \\
\hline Total & $7.55 \pm 6.62^{\mathrm{a}}$ & & $17.40 \pm 4.15^{\mathrm{b}}$ & & $14.96 \pm 5.87^{c}$ & \\
\hline
\end{tabular}

${ }^{*} \mathrm{p}<0.0001 ;{ }^{* *} \mathrm{p}<0.03,{ }^{\mathrm{a}} \mathrm{p}<0.000$., significance difference between concessions in the same country, value with different letters indicate significance difference between country

level showed that almost all the surveyed household in the DRC and Gabon (92.9 \% and $92.7 \%$ respectively) experienced severe and/or mild food insecurity indicating how difficult the populations in these forest concessions obtain the food they need. The rates of household food insecurity in the DRC $\left(\mathrm{X}^{2}=176.59 ; \mathrm{p}<0.0001\right)$ and Gabon $\left(\mathrm{X}^{2}=262.11 ; \mathrm{p}<0.0001\right)$ were shown to be significantly higher when compared to household food insecurity rate in Cameroon.

\section{Household food insecurity status in the surveyed villages} Food insecurity status also varied among the villages around each concession. In Cameroon, households at greatest level of food insecurity were found in four of the seven villages around SCTB concession. The most affected were Melambo (56.5\%), Bonando (88.2 \%), Petit Pol (93.2 \%) and Kouedjina (100\%). Two of the remaining villages were totally food secured (Ndembo and Nkolbikon) while in the last village (Kagnol), up to $70 \%$ of households were food secured. In the DRC, households in villages around COTREFOR experienced the greatest level of food insecurity (65-100\%) while around CFT; households in all the six villages were totally food insecured. The same trend was observed in villages around the forest concessions of Gabon where $76.2-100 \%$ of the surveyed households experienced food insecurity (Table 4).

\section{Household characteristics that influence susceptibility to food insecurity among households adjoining the selected forest concessions \\ Gender and food insecurity}

The most food insecure households were headed by women (Table 5). The difference was significant around SCTB, COTREFOR and Bayonne.

\section{Socioeconomic wealth index, Source of income, Educational level and food Insecurity}

As shown in Table 6, the Socioeconomic Wealth Index (SES) and food insecurity were inversely related, with the lowest SES score observed in households at greatest levels of food insecurity. The relationship between the socioeconomic wealth index and food security status scores was significant $(\mathrm{p}<0.001)$, with a moderate correlation $(\mathrm{cc}=-0,290)$.

The lowest proportion of food insecure households have income derived from agriculture in combination with logging (36.4 \%) or trading (33.3\%), whereas

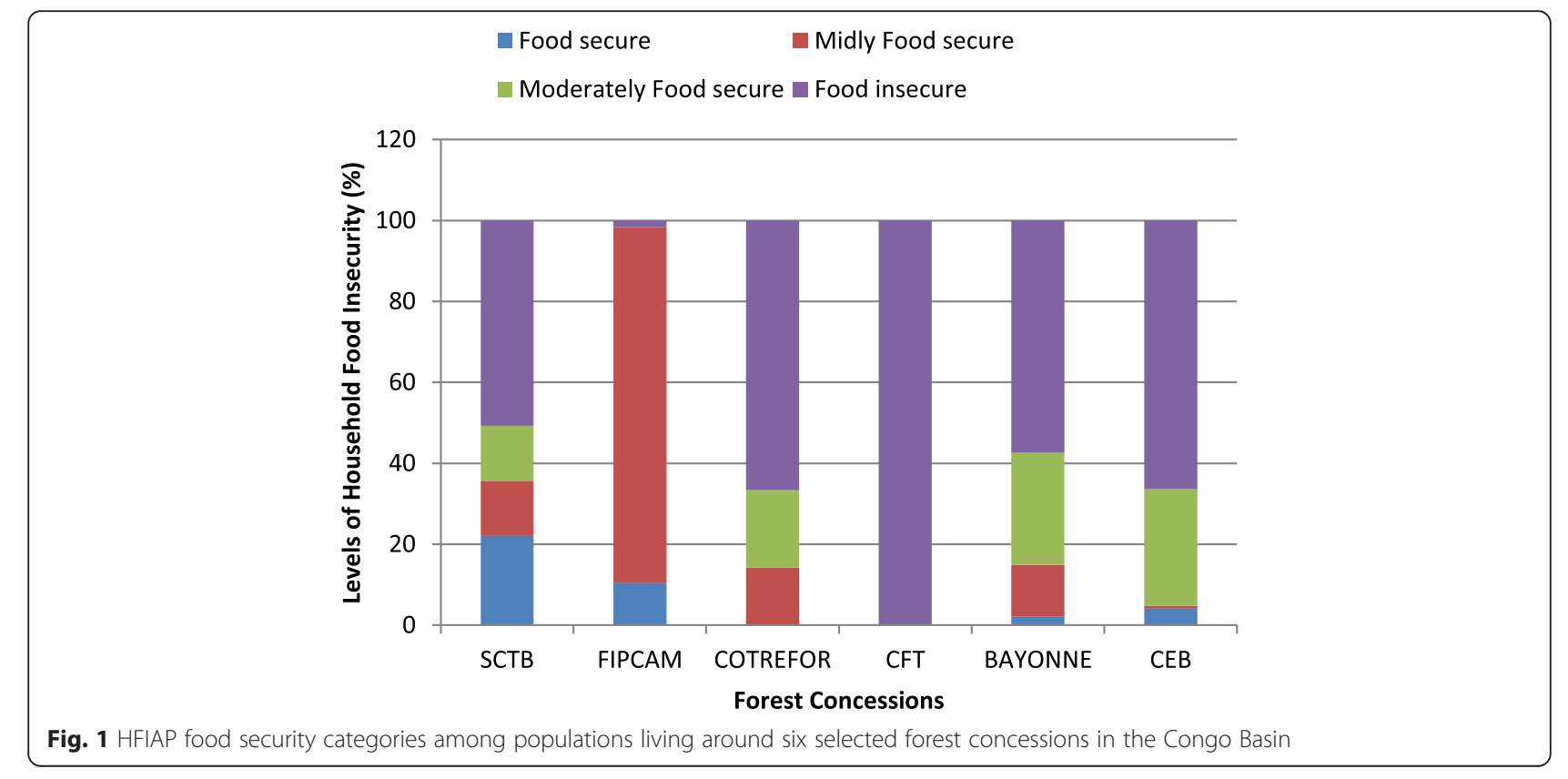




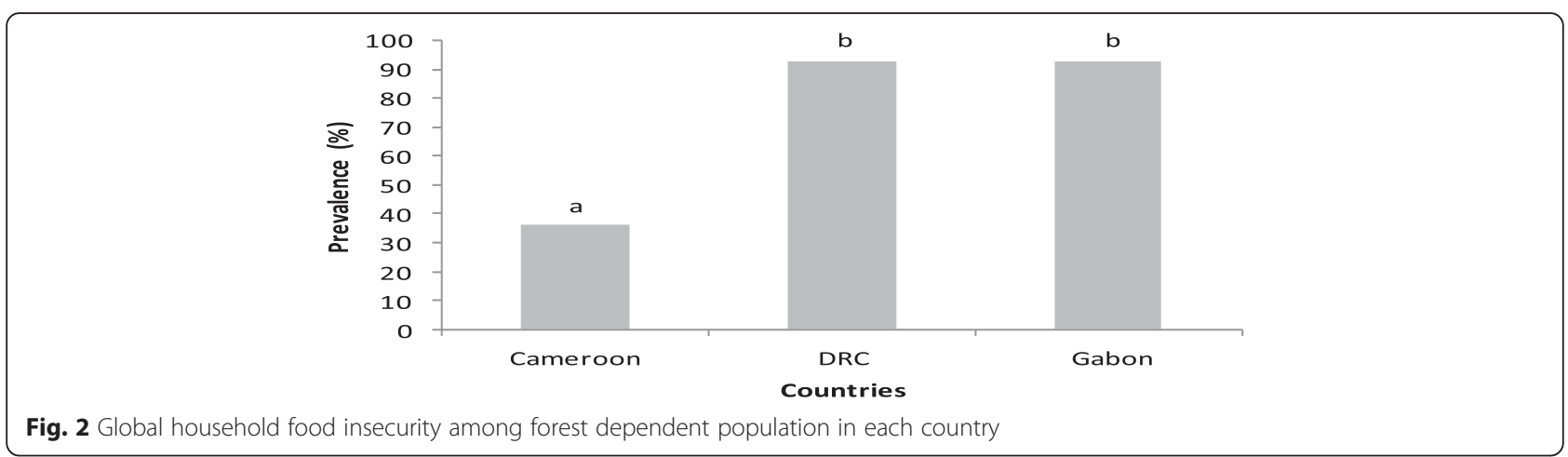

households that completely depended on agriculture had greater prevalence $(67.4 \%)$ of food insecurity (Table 6).

The rate of food insecurity decreases with the level of education. Households headed by a member with secondary educational status exhibited a lower rate of food insecurity (24\%) compare to households headed by members with no formal education $(79.7 \%)$ or primary education $(57.5 \%)$. This association between the educational level and the rate of food insecurity was statistically significant $(\mathrm{p}<0.0001, \mathrm{cc}=-0.255)$.

\section{Discussion}

The forest of the Congo Basin harbors more than 30 million people and sustains the lives of approximately 75 million people from 150 ethnic groups and beyond. The global food security status around forest concessions for each country showed that most Congolese and Gabonese households were food insecure compared to households around forest concessions in Cameroon. The alarming rate of food insecurity around the five affected forest concessions may be explained by poor diets linked to the lack of sufficient quantities of forest products. In 2010, the World Food Program reported an estimated $12 \%$ of households in the DRC exercising poor food consumption, $21 \%$ with borderline food consumption and $67 \%$ with acceptable food consumption. In most parts of the Congo Basin, forests play central roles in the sustainability of rural livelihoods [25]. It provides wild foods and assures a balanced and varied diet, thus contributes in ameliorating the health of forest dependent populations [26]. Forest products like trees, herbs, mushrooms and animals contribute in many ways to improve food security by providing ready accessibility to affordable and often highly nutritious foods [27-29]. Knowing that only a few communities in the world currently rely on forest foods for a complete diet [30, 31]), it is also important to recognize the role of forest foods in maintaining quality household nutrition especially during the lean season when agricultural production is low, periods of climate-induced vulnerability, and food gaps due to other cyclical events [32, 33] like inundations and landslides.

In the DRC, the 2010 MICS survey showed that, households generally produced the following foods; roots and tubers, fruits, corn, vegetable, and oilseeds. Other foods are mainly obtained by purchases at the market, especially in urban centers. These foods are milk (93\%), sugar (91\%), rice (70\%), palm oil (69\%), meat (68\%) and legumes (58\%). The study also showed that own household production, and other food sources are unable to meet the food needs of the majority of households, still maintaining the country in a state of food insecurity [4]. The two industrial forestry companies COTREFOR and CFT are located around Kisangani in the Eastern province of DRC, which is among the provinces where more than half the population $(57 \%)$ is food insecure [34]. The alarming rate (66-100\%) of food insecurity among households adjoining the two concessions was higher compared to the global prevalence in that province (57 \%) [34]. In Gabon, data on food security status are only available at the nationwide level and not at the individual household level [9].

Many factors can explain the alarming rate of household food insecurity around the five affected concessions in the Congo Basin. The main reason is probably deforestation with enormous negative impacts on important forest product availability desired by local populations [26]. It was shown that, forests contribute to food security in many diverse ways including its protective environmental role and provision of ecosystem services [35]. Although forest foods rarely represent staples in diets and rarely constitute an important proportion of diets (in number or volume), they go a long way to supplement household agricultural production and other resources for many rural people: Forests provide a diversity of healthy foods, high in micronutrients and fibers and low in sodium, refined sugar and fat [8] and help households fill seasonal and other cyclical food gaps, acting as a 'safety net' or 'buffer' in times of shortages due to drought, crop failure, pathologies or other emergency or external shocks [8]. This is not the case in this study 
Table 4 Household Food insecurity status in the surveyed villages around the six forest concessions

\begin{tabular}{|c|c|c|}
\hline Forestry companies & Villages & Food insecure $\%(n)$ \\
\hline \multirow[t]{7}{*}{ SCTB } & Bonando & $88.2(30)$ \\
\hline & Petit Pol & $93.2(41)$ \\
\hline & Nkolbikon & 0 \\
\hline & Ndembo & 0 \\
\hline & Melambo & $56.5(13)$ \\
\hline & Kagnol & $29.4(5)$ \\
\hline & Kouedjina & $100(10)$ \\
\hline \multirow[t]{5}{*}{ FIPCAM } & Ondondo & $5.1(2)$ \\
\hline & Ngon & 0 \\
\hline & Methyikpwale & 0 \\
\hline & Bissam & 0 \\
\hline & Meyos & 0 \\
\hline \multirow[t]{6}{*}{ COTREFOR } & Batshepo & $100.0(21)$ \\
\hline & Babongena & $95(19)$ \\
\hline & Bambudje & $81(17)$ \\
\hline & Batianyoka & $77.8(14)$ \\
\hline & Basayo & $95(19)$ \\
\hline & Kayete & $65(13)$ \\
\hline \multirow[t]{6}{*}{ CFT } & Pumuzika & $100.0(20)$ \\
\hline & Yonga & $100.0(20)$ \\
\hline & Maweda & $100.0(20)$ \\
\hline & Abgokanga & $100.0(20)$ \\
\hline & Mangobo & $100.0(20)$ \\
\hline & Kazombo & $100.0(20)$ \\
\hline \multirow[t]{4}{*}{ Bayonne } & Douano & $94.4(17)$ \\
\hline & Mandilou & $76.2(16)$ \\
\hline & Minganga & $85.7(6)$ \\
\hline & Tondondo & $100(1)$ \\
\hline \multirow[t]{6}{*}{ CEB } & Lekori & $96.7(29)$ \\
\hline & Mbounga & $100(23)$ \\
\hline & Minganga & $97(32)$ \\
\hline & Opoungou & $100(15)$ \\
\hline & Otala & $82.8(24)$ \\
\hline & Otondou & $100(2)$ \\
\hline
\end{tabular}

probably due to the exclusion of households directly involve in commercial exploitation of the forest as their involvement in logging is often considered illegal.

In this study, we observed that factors such as the socioeconomic status, educational level, gender and the age of the household affected the rate of food insecurity in the Congo Basin. The study also isolated households headed by females as main cases of high food insecurity. Vinceti et al. [28] reported that "people at risk of food insecurity, hunger or malnutrition generally have the
Table 5 Gender and food security status

\begin{tabular}{lll}
\hline Forestry companies & Head of household & Food insecure \\
\hline SCTB & Male & $56.4(66)^{* *}$ \\
& Female & $89.2(33)$ \\
FIPCAM & Male & $1.1(1)^{\mathrm{ns}}$ \\
& Female & $2.6(1)$ \\
COTREFOR & Male & $81.5(75)^{* *}$ \\
& Female & $100(28)$ \\
CFT & Male & $100(92)^{\mathrm{ns}}$ \\
& Female & $100(28)$ \\
BAYONNE & Male & $88.6(31)^{*}$ \\
& Female & $70(7)$ \\
CEB & Male & $93(66)^{\mathrm{ns}}$ \\
& Female & $97.3(73)$ \\
\hline
\end{tabular}

${ }^{*} p<0.01 ; * * p<0.0001$ significance level compared to female

highest degree of reliance on forest products for income and food" and this ties to the dependence of women on forest products; especially firewood and wild food plants than men in this region. In addition to the consequences of division of labor women may also be more vulnerable when changes in forest management or deforestation alter their access to forest products. Forest foods have also been suggested to provide a "safety net" in times of food scarcity and uncertainty [36]. The educational level of our studied population was negatively associated to the rate of food insecurity. This could be explained by the fact that educated household heads have increase awareness on the possible advantages of modern agriculture and could easily embrace technological inputs. Educated household heads also have the capacity to read instructions on agricultural equipment like fertilizer packages and can as well diversify household income. All these would enhance households' food supply [15]. The ages of household heads were also inversely related to the rate of food insecurity and this is in line with the results of Obamiro et al. [37]. On the contrary, another study showed that the older the household head, the more stable the economy of the farm household [37] and there is really no argument with this result as older household heads are expected to have better access to land than younger household heads.

The source of income also affects the rate of food insecurity in the Congo Basin. A lower rate of food insecurity was noticed among households whose main sources of income were agriculture in combination with illegal logging and trading of forest products. Literature highlights the contribution of forest products in ameliorating household income and reducing poverty, through the marketing of harvested plants and hunted animals particularly by poor rural people in forest communities [38]. Earlier studies in West Africa laid bush meat 
Table 6 Household characteristics and food security status

\begin{tabular}{llll}
\hline Variables & Attributes & $\begin{array}{l}\text { Food } \\
\text { Secure (\%) }\end{array}$ & $\begin{array}{l}\text { Food } \\
\text { insecure (\%) }\end{array}$ \\
\hline Age groups & $\leq 30$ & 13.7 & $11.3^{\mathrm{ns}}$ \\
& $31-39$ & 20.0 & $16.2^{\mathrm{ns}}$ \\
& $40-49$ & 24.2 & $21.4^{\mathrm{ns}}$ \\
& $50-59$ & 22.1 & $22.9^{\mathrm{ns}}$ \\
& 60 and above & 20.0 & $28.2^{\mathrm{ns}}$ \\
Educational level & No formal education & 20.3 & $79.7^{*}$ \\
& Primary education & 42.5 & $57.5^{*}$ \\
Gender & Secondary education & 76 & $24^{*}$ \\
& Male headed & 33 & $67^{*}$ \\
Household wealth & Female headed & 21.3 & $78.7^{*}$ \\
index scores & Poorest & 31.8 & $68.2^{* *}$ \\
Source of income & Least poor & 61.4 & $38.6^{* *}$ \\
& Agriculture & 32.6 & $67.4^{* *}$ \\
& Agriculture and & 63.6 & $36.4^{* *}$ \\
& illegal logging & & \\
& Agriculture and & 66.7 & $33.3^{* *}$ \\
\hline
\end{tabular}

${ }^{*} p<0.01 ;{ }^{* *} p<0.0001$ significance level compared to food secured households

ns: non significant

business as the main income generating activity for forest depended communities [39]. Puustjarvy et al. [40] reported a contribution from forest products to total household income of about $50 \%$ in Luapula and Northwestern Provinces of Zambia. NTFPs are particularly important in supporting poor households because of inexpensive extraction technology and ease of access [41, 42] even though a minimum level of technical skills is required for a fruitful exploitation of the forest.

\section{Conclusion}

The study examined the household food security status in 34 communities living around six forest concessions in the Congo Basin. Based on results obtained, an alarming rate of household food insecurity was documented in five forest concessions; the four concessions of the DRC and Gabon and one of Cameroon. Thus, Congolese and Gabonese households were more affected. Poverty, low educational level, and youthfulness are the main food insecurity determinants in the region. The study also found that food security has a gender dimension, with female headed households being the most food insecure. Agriculture in association with illegal logging and the trading of forest products are important sources of income amongst food secure households. Therefore, the proper management of forest resources relies on educating the population, with the main target being youths and women. This strategy will certainly contribute in reducing the high food insecurity rates common amongst the populations around the forest concessions of the Congo Basin.

\begin{abstract}
Abbreviations
BAYONNE, SUN HARVEST Bayonne; CC, correlation coefficient; CEB, Compagnie Equatoriale des Bois; CFT, Compagnie Forestière de Transformation; COTREFOR, Compagnie de Transport et d'Exploitation Forestière; DMI, Donald Midoko Iponga; DP, Pauline Donn ; DRC, Democratic Republic of Congo; ENA, NTFPs, Non Timber Forest Products; FANTA, Food and Nutrition Technical Assistance; FAO, Food and Agriculture Organization of the United Nations; FIPCAM, Fabrique Camerounaise de Parquet; HFIAP, Household Food Insecurity Access Prevalence; HFIAS, Household Food Insecurity Access Scale; IFPRI , International Food Policy Research Institute; IFRCRCS, International Federation of Red Cross and Red Crescent Societies; IUCN, International Union for the Conservation of Nature; JMKJJean Marie Kahindo; JT, Julius Tieguhong; MICS, Multiple Indicator Cluster Survey; MT, Mathurin Tchatat; NJL, Ngondi Judith Laure; OT, Obadia Tchingsabe; PNIA, Plan national d'investissement agricole; RF, Robert Fungo; RReCSuD, The Regional Research Center for Sustainable Development; SCTB, Societe Camerounaise de Transformation du Bois; SES, socioeconomic status; WFP, World Food Programme; WHO, World Health Organization.
\end{abstract}

\section{Acknowledgements \\ We thank the national project partners. Notably the University of Kisangani (UNIKIS), the Research Institute in Tropical Ecology (IRET) and the Institute of Agricultural Research for Development (IRAD) for their assistance in data collection. We equally thank the concessionaries for their consistent collaboration and support throughout the study period. We express our gratitude to all the different component leaders of this project and those that participated in field data collection, particularly the socio-economic team led by CIFOR. We equally express our gratitude to all the inhabitants of the 34 villages, for their hospitality, participation and collaboration throughout the data collection period.}

\section{Funding}

This work falls within the «Beyond Timber project» activities. The Congo Basin Forest Fund (CBFF) and the CGIAR Research Program on Forests, Trees and Agroforestry (FTA) provided the finances that help in executing all aspects of this work.

\section{Availability of data and materials}

Data would not be shared as only the treated data will be made available through publications.

\section{Authors contributions}

PD: contributed in sampling, data entry and drafting of the manuscript; OT \&RF contributed in sampling, data entry and cleaning as well as literature reviews. NJL performed the statistical analysis and drafted the manuscript. JT, MT, DMI and JMK conceived and design the protocol, supervised field work and revised the manuscript. All authors read and approved the final manuscript.

\section{Competing interests}

No conflict of interest from authors

\section{Consent to publish}

Not applicable.

\section{Ethics approval and consent to participate}

The Beyond Timber Project was assessed by the forestry authorities of each country and research permits were issued to the Centre for International Forestry Research (CIFOR) in the three countries and the national project partners, notably the University of Kisangani (UNIKIS) in DRC, the Research Institute in Tropical Ecology (IRET) in Gabon and the Institute of Agricultural Research for Development (IRAD) in Cameroon for data collection. In addition, the study was approved by the Cameroon National ethical committee, where as in Gabon and DRC, approval was obtained from institutional ethics committee of national partners' institutions.

Community consent was systematically obtained from the village head and the verbal consent for the participation was obtained from each household 
head because most of them were illiterate. Each household head was provided with a description and the purpose of the study in vernacular language by the local guide who signed the consent form on behalf of those who accepted to participate. A copy of the informed consent was given to household head who could read French. The supervision of all the process was assured by the village head. In addition, it was also emphasized that household heads could voluntarily withdraw from the study at their convenience with or without any necessary explanation. The Ethics Committees of the three countries involved in the study approved the use of oral consent.

\section{Author details}

${ }^{1}$ Bioversity International, Yaoundé, Cameroon. ${ }^{2}$ University of Kisangani, Kisangani, DRC, Africa. ${ }^{3}$ Institut de Recherche Agricole pour le Développement (IRAD), Yaounde, P.O. Box 2785, Cameroon. ${ }^{4}$ Department of Biochemistry, University of Yaounde 1, Yaounde, Cameroon. Institut de Recherche en Ecologie Tropicale, Libreville, P.O. Box 13345, Gabon. ' Makerere University, School of food Technology, Nutrition and Bio-engineering, Kampala, P.O. Box 7062, Uganda. ${ }^{7}$ The Regional Research Center for Sustainable Development, RReCSuD-Cameroon, Yaounde, P.O. Box 33297, Cameroon.

\section{Received: 17 August 2015 Accepted: 27 May 2016 Published online: 10 June 2016}

\section{References}

1. https://www.ifpri.org/blog/boosting-both-food-security-and-forest-resourcesrequires-new-thinking IUCN Forest, June 2014.

2. The World Bank. Deforestation Trends in the Congo Basin: Reconciling Economic Growth and Forest Protection. Working Paper 2: Logging. 2013.

3. Nasi R, Cassagne B, Billand A. "Forest mmanagement in Central Africa: Where Are We?". Int For Rev. 2006;8(1):14-20.

4. Caldecott, cited in Aiken and Leigh. Vanishing Rainforests The Ecological transition in Malaysia; 1992. p102-3.

5. IUCN, pers com 05/08/98

6. Ndoye, O., Perez, M. R. et Eyebe, A. (1997) The market of Non-timber Forest Products in the Humid Forest Zone of Cameroon. Network Paper 22C.

7. Watson F. "A view from the forest floor: the impact of logging on indigenous peoples in Brazil". Bot J Linn Soc (1996). 1996;122:75-82.

8. Arnold M, Powell B, Shanley P \& Sunderland TCH. EDITORIAL: Forests, biodiversity and food security. International Forestry Review. 2011 Vol.13 (3).

9. FAO. (2009). Declaration of the World Summit on Food Security.Rome. 7 pp. (Website: http://ftp.fao.org/docrep/fao/Meeting/018/k6050e.pdf).

10. Girma Gezimu Gebre. Determinants of food insecurity among households in Addis Ababa city, Ethiopia. Interdisciplinary Description of Complex Systems. 2012); 10(2), 159-173.

11. Bickel G, Nord M, Price C, Hamilton W, Cook J. Guide to Measuring Household Food Insecurity, Revised 2000. U.S: Department of Agriculture,Food and Nutrition Service, Alexandria, VA; 2000.

12. Grebmer K, Ruel M, Oppeln C, et al. Global Hunger Index: The Challenge of Hunger: Focus on the Crisis of Child Undernutrition. Bonn, Washington DC \& Dublin: Welt Hunger Hilfe, IFPRI \& Concern Worldwide; 2010.

13. Paddy, F.(2003). Gender differentials in land ownership and their impact on household food security: a case study of Masaka district. Master thesis. Uganda. (Website: http://www.troz.uni-hohenheim.de/research/Thesis/ MScAES/Paddy.pdf).

14. Najafi B. An Overview of Current Land Utilization Systems and Their Contribution to Agricultural Productivity. Report of the APO Seminar on Impact of Land Utilization Systems on Agricultural Productivity. Productivity Organization: Islamic Republic of Iran Asian; 2003.

15. Foster $P$ (1992). The World Food Problem: Tackling the causes of under nutrition in the third World, Lynee Rienner publishers, Boulder, Colorado, In: Feleke S (2003). Determinants of Food Security in Southern Ethiopia. Selected paper presented at the 2003 American Agricultural Economics Association Meetings in Montreal, Canada, University of Florida, USA.

16. Govereh J \& Jayne TS. Policy Synthesis: Effects of Cash Crop Production on Food Crop Productivity in Zimbabwe: Synergies Or Trade-Offs?. USAID Africa Bureau, Office of Sustainable Development No 40; 1999.

17. WFP (2012), Country Summaries - Annex to the global food security update - December 2012

18. PNIA (2013), Ministry of Agriculture "Plan national d'investissement agricole (PNIA) 2013-2020 p.5.
19. MICS(2010): http://www.childinfo.org/files/MICSRDC_2010_Preliminary_ Results final_EN_imprime.pdf

20. Falconer J, Arnold JEM. Social Forestry Network Paper 7a. London: Overseas Development Institute; 1988. Forest, trees and household food security.

21. Rist L, Shanley P, Sunderland T, Sheil D, Ndoye O, Liswanti N, Tieguhong J. The impacts of selective logging on non-timber forest products of livelihood importance. Forest Ecol Manag. 2012;268:57-69.

22. Swindale A, Bilinsky P. "Household Dietary Diversity Score (HDDS) for Measurement of Household Food Access: Indicator Guide (Version 2)". Washington, D.C: Food and Nutrition Technical Assistance Project Academy for Educational Development; 2006.

23. Faber M, Schwabe C, Drimie S. "Dietary Diversity in Relation to Other Household Food Security Indicators". Int J Food Saf Nutr Public Health. 2009;2(1):1-15.

24. Garenne M, Hohmann S. "A wealth index to screen high risk families: application to Morocco". J Health Popul Nutr. 2003;21(3):235-42.

25. Tieguhong JC, Mala WA, Ndoye O, Grouwels S, Useni KM, Betti JL. Rural enterprise development for poverty alleviation based on non-wood forest products in Central Africa. Int For Rev. 2012a;14(3):363-79.

26. Ndoye O, Tieguhong JC. Forest Resources and Rural Livelihoods: The Conflict between Timber and Non-timber Forest Products in the Congo Basin. Scand J For Res. 2004;19:36-44.

27. Dansi A, Adjatin A, Adoukonou-Sagbadja H, Faladé V, Ydomonhan $H_{\text {, }}$ Odou D, Dossou B. Traditional leafy vegetables and their use in the Benin Republic. Genetic Resources and Crop Evolution. 2008;55:1239-1256.

28. Vinceti $B$, Eyzaguirre $P$, Johns $T$. The nutritional role of forest plant foods for rural communities (Chapter 4). In: COLFER CJP, editor. Human health and forests: a global overview of issues, practice and policy. London: Earthscan; 2008.

29. Powell B, Watts J, Boucard A, Urech Z, Feintrenie L, Lyimo E, Asah S, Sunderland-Groves J. The Role of Wild Species in the Governance of Tropical Forested Landscapes, Chapter 7. In: Colfer CJP, J-I P, editors. Collaborative Governance of Tropical Landscapes. London: Earthscan; 2010.

30. Mercader J. Forest people: the role of African rainforests in human evolution and dispersal. Evol Anthropol. 2002;11(3):117-24.

31. Colfer CJP, Sheil D, Kishi M. Forests and human health: assessing the evidence. Occasional Paper No.45. Bogor: CIFOR; 2006.

32. Angelsen, A.: Wunder, S.; Babigumira, R.; Belcher, B.; Börner, J.: Smith-Hall, C. Environmental Incomes and Rural Livelihoods: A Global-Comparative Assessment; Brazilian Institute of Geography and Statistics/Food and Agricultural Organization: Paper presented at the 4th Wye Global Conference, Rio de Janeiro, country, 9-11 November 2011. Available online: http://www.fao.org/fileadmin/templates/ess/pages/rural/wye_city_group/ 2011/documents/session4/Angelsen_Wunder_Babigumira_Belcher_Birner_ Smith-Hall-Paper.pdf. (Accessed on 23 Mar 2014).

33. Faye MD, Weber JC, Abasse TA, Boureima M, Larwanou M, Bationo AB, Diallo BO, Sigué H, Dakouo JM, Samaké O, Sonogo Diaité D. Farmers' preferences for tree functions and species in the West African Sahel. For Trees Livelihoods. 2010b;20(2-3):113-36.

34. Ferrarro PJ, Hanauer MM. Protecting ecosystems and alleviating poverty with parks and reserves: "win-win" or tradeoffs? Environ Resour Econ. 2011;48:269-86

35. Mcsweeney K. Forest product sale as natural insurance: the effects of household characteristics and the nature of shock in eastern Honduras. Soc Nat Resour. 2004):17(1):39-56.

36. Obamiro EO, Doppler, kormawa PM(2003). Pillars of Food Security in Rural Areas of Nigeria. Food Africa, Internet Forum 31 March - 11 April, Internet Paper accepted for the Food Security Theme. Available online https://www.hitpages.com/doc/6107880776269824/1/

37. Hofferth SL (2003). Persistence and Change in the Food Security of Families with Children, 1997-1999. Department of Family Studies, University of Maryland. (Website:http://www.findarticles.com/p/articles/mi_m1309/is_3_ 40/ai_111027115)

38. Belcher B, Ruizperez M, Achdiawan R. Global patterns and trends in the use and management of commercial NTFPs: Implications for livelihoods and conservation. World Dev. 2005:33:1435-52.

39. De Merode E, Homewood k \& Cowlishaw G. Wild resources and livelihoods in Democratic Republic of Congo. ODI Wildlife Policy Briefing, No. 1, Overseas Development Institute. 2003.

40. Puustjarvy E, Mickels-Kokwe G, Chakanga M. Report prepared by INDUFOR for the Forestry Department, Zambia, and The Ministry of Foreign Affairs of 
Finland. Helsinki: INDUFOR; 2005. The Contribution of the Forestry Sector to the National Economy and Poverty Reduction in Zambia.

41. Jimoh SO. Sustaining the Roles of Non-Timber Forest Products in Rural Poverty. 2006

42. Tieguhong JC, Nkamgnia EM. Household dependence on forests around Lobeke National Park, Cameroon. Int For Rev. 2012;14(2):196-212.

Submit your next manuscript to BioMed Central and we will help you at every step:

- We accept pre-submission inquiries

- Our selector tool helps you to find the most relevant journal

- We provide round the clock customer support

- Convenient online submission

- Thorough peer review

- Inclusion in PubMed and all major indexing services

- Maximum visibility for your research

Submit your manuscript at www.biomedcentral.com/submit 